\title{
A Novel Chlorin Derivative of Meso-tris(pentafluorophenyl)-4-pyridylporphyrin: Synthesis, Photophysics and Photochemical Properties
}

\author{
Ana Paula J. Maestrin ${ }^{a}$, Anderson O. Ribeiro ${ }^{a}$, Antonio Cláudio Tedesco ${ }^{a}$, Cláudio R. Neri ${ }^{a}$, Fábio $S$. \\ Vinhado $^{a}$, Osvaldo A. Serra ${ }^{*, a}$, Patrícia R. Martins $^{a}$, Yassuko Iamamoto ${ }^{a}$, Ana Margarida G. Silva ${ }^{b}$, \\ Augusto C. Tomé ${ }^{b}$, Maria G. P. M. S. Neves ${ }^{b}$ and José A. S. Cavaleiro ${ }^{*, b}$ \\ ${ }^{a}$ Departamento de Química, Faculdade de Filosofia Ciências e Letras de Ribeirão Preto, Universidade de São Paulo, \\ 14040-901 Ribeirão Preto - SP, Brazil \\ ${ }^{b}$ Departamento de Química, Universidade de Aveiro, 3810-193 Aveiro, Portugal
}

\begin{abstract}
A terapia fotodinâmica (TFD) está baseada na administração e no acúmulo de fotossensibilizador, por exemplo, de tipo porfirina ou clorina, em tecidos doentes. As clorinas apresentam propriedades fotofísicas semelhantes àquelas das porfirinas, mas com intensificação e deslocamento das bandas Q, o que faz com que sejam bons candidatos para TFD. Neste trabalho relata-se a síntese da 5,10,15tris(pentafluorofenil)-20-(4-piridil)porfirina, (2), e das clorinas isômeras $\mathbf{4},(5,10,20$ tris(pentafluorofenil)-15-(4-piridil)-tetra-hidro- $1 H$ - $N$-metil-pirrolo[3,4-b]porfirina e 5, $(5,10,15$ tris(pentafluorofenil)-20-(4-piridil)-tetra-hidro- $1 \mathrm{H}-\mathrm{N}$-metil-pirrolo[3,4-b]porfirina, obtidas a partir de 2, por reação de cicloadição 1,3-dipolar com um ileto azometínico, e respectivas caracterizações estruturais por UV-Vis, RMN e EM-FAB. Foram avaliadas as propriedades fotofísicas, fotoquímicas e fotodegradativas para a nova clorina $\mathbf{4}$, obtida com melhor rendimento que o seu isômero $\mathbf{5}$. O rendimento quântico de fotodegradação $\left(\phi_{\mathrm{Fd}}\right.$, mol Einstein $\left.{ }^{-1}\right)$ foi de $0,047 \pm 0,014$. Foram ainda realizados testes com ácido úrico para demonstrar a capacidade do fotossensibilizador na produção de ${ }^{1} \mathrm{O}_{2}$. Os resultados mostraram que a nova clorina 4 pode ser considerada como um bom fotossensibilizador para TFD.
\end{abstract}

Photodynamic therapy (PDT) is based on the accumulation of a photosensitizer, such as a porphyrin or a chlorin, in a malignant tissue after its administration. Chlorins exhibit photophysical properties similar to those of the porphyrin macrocycles, but with intensified and red-shifted Q bands, making chlorin-containing systems even better candidates for PDT. In this contribution, we report the synthesis of 5,10,15-tris(pentafluorophenyl)-20-(4-pyridyl)porphyrin, (2) and its transformation to the novel chlorin derivatives 4, (5,10,20-tris(pentafluorophenyl)-15-(4-pyridyl)tetrahydro- $1 \mathrm{H}$ - $\mathrm{N}$-methyl-pyrrolo [3,4-b]porphyrin and 5, (5,10,15-tris(pentafluorophenyl)-20-(4pyridyl)-tetrahydro- $1 H$ - $N$-methyl-pyrrolo[3,4-b]porphyrin) by 1,3-dipolar cycloaddition with an azomethine ylide. The new products have been characterized by UV-Vis, ${ }^{1} \mathrm{H}$ NMR and FAB-MS. The photophysics, photochemical and photobleaching properties of chlorin $\mathbf{4}$ have been evaluated. Its quantum yield of photobleaching $\left(\phi_{\mathrm{Pb}}\right.$, mol Einstein $\left.{ }^{-1}\right)$ was $0.047 \pm 0.014$. In order to demonstrate the production of ${ }^{1} \mathrm{O}_{2}$ when $\mathbf{4}$ is used as a photosensitizer, uric acid tests have been carried out. The results indicate that chlorin $\mathbf{4}$ can be considered a promising photosensitizer in PDT.

Keywords: photosensitizer, photodynamic activity, chlorins, photobleaching

\section{Introduction}

Macrocyclic tetrapyrrolic metal complexes have been investigated for a few decades on account of their catalytic properties. They are capable of catalyzing a wide range of oxidation reactions: from hydroxylation of alkanes and epoxidation of alkenes to drug oxidation and DNA

* e-mail: jcavaleiro@dq.ua.pt; osaserra@ffclrp.usp.br cleavage. ${ }^{1-3}$ More recently, porphyrins have attracted even more attention from researchers in various fields due to their phototherapeutic properties. ${ }^{4-6}$

Photodynamic therapy (PDT) is a form of neoplastic diseases treatment using a photosensitizer, oxygen and light. The exogenous photosensitizer localises in tumours with a high degree of selectivity after its administration. Subsequent irradiation with visible or near infrared light induces a photodynamic effect. Such effect is generally 
regarded as being mainly due to the reaction of biomolecules with singlet oxygen generated in situ, and tumour cells are preferentially destroyed. ${ }^{7}$

Porphyrin derivatives and related systems have been used as photosensitizers used in cancer phototherapy. $\mathrm{HpD}$ (Hematoporphyrin Derivative) and its more purified versions, such as Photofrin ${ }^{\circledR}$, Photosan ${ }^{\circledR}$ and Photogem ${ }^{\circledR}$ have regulatory approval; however, they are complex mixtures of oligomers with the weak absorption features of porphyrins around $620 \mathrm{~nm}$. They are considered the first generation of PDT photosensitizers. However, the high degree of skin photosensitivity is a major drawback in the use of such compounds. ${ }^{8-11}$

In order to develop new photosensitizers with improved characteristics (such as greater selectivity for target cells or tissues and higher maximum light-absorption to allow deeper tissue penetration, a large number of porphyrinrelated compounds like chlorins (dihydro-type porphyrins), bacteriochlorins (tetrahydro-type porphyrins) and also expanded porphyrins containing a variety of substituents have been synthesized. ${ }^{8,9}$

As mentioned by Pandey and Zheng ${ }^{10}$ based on the Cubeddn et al.'s report, ${ }^{11}$ chlorins exhibit photophysical properties similar to those of the porphyrin system, but have enhanced and red-shifted Q bands which make chlorin-containing systems better candidates for PDT. Ideally, these drugs should accumulate very rapidly in tumour tissues and optimal times for irradiation treatment are estimated to lie between $30 \mathrm{~min}$ and 2.5 hours following intravenous administration.

Some of us ${ }^{12,13}$ have already reported good yields in the synthesis of new chlorin and bacteriochlorin derivatives by Diels-Alder or 1,3-dipolar cycloaddition reactions of meso-tetraarylporphyrins with adequate dienes or 1,3-dipoles (e.g., azomethine ylide - Scheme 1).

Our aim is to synthesize new porphyrins and employ them in cycloaddition transformations leading to novel chlorin derivatives that can be considered as potential PDT candidates.

In this work, we report the synthesis and structural characterization (UV-Vis spectra, FAB-MS and ${ }^{1} \mathrm{H}$ NMR) of 5,10,15-tris(pentafluorophenyl)-20-(4-pyridyl) porphyrin, (2), and its use as a dipolarophile in a 1,3-dipolar cycloaddition with the azomethine ylide generated in situ from $N$-methylglycine and paraformaldehyde (Scheme 2). The two isomeric chlorins $\mathbf{4}$ and $\mathbf{5}$ have been obtained and characterized.

Photodynamic activity depends on the production of reactive oxygen species, such as ${ }^{1} \mathrm{O}_{2}$ and its quantum yield. In order to verify the new chlorins ability to act as photosensitizers in PDT, tests with uric acid, a known singlet oxygen scavenger, were performed with chlorin $3(5,10,15,20-$ tetrakis(pentafluorophenyl)-tetrahydro-1H-N-methylpyrrolo-porphyrin) (this one being used for comparison purposes) and $\mathbf{4}$, the new one formed in higher yield. ${ }^{14}$

\section{Materials and Methods}

\section{Chemicals}

All solvents and reagents were purchased from Merck, Synth, Losco Chemical, Nuclear or Aldrich. Pyrrole was distilled under reduced pressure immediately before use. Dichloromethane was kept over anhydrous $\mathrm{CaCl}_{2}$ for 2.5 $\mathrm{h}$, and was then filtered and distilled over $\mathrm{P}_{2} \mathrm{O}_{5}$ and stored over $4 \AA$ molecular sieves.

\section{Equipment and chromatographic conditions}

The UV-Visible spectra were recorded on a Hewlett Packard 8453 spectrophotometer using 10 or $2.0 \mathrm{~mm}$ quartz cells.

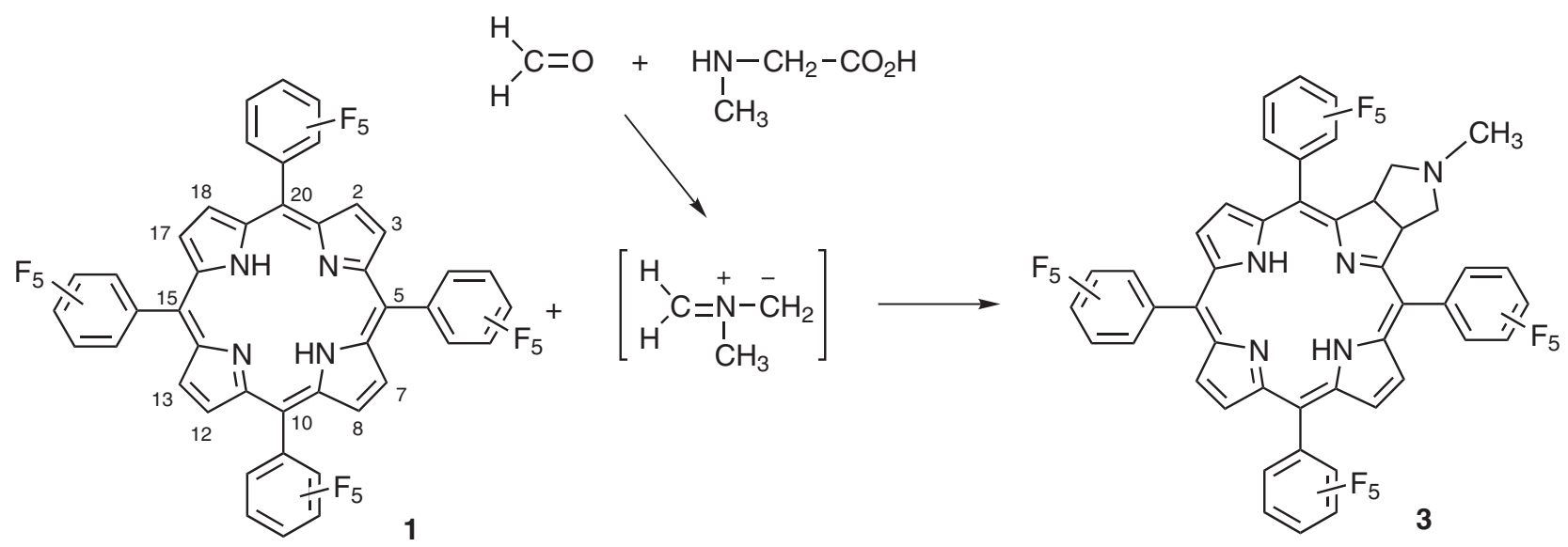

Scheme 1. Synthesis of chlorin $\mathbf{3}$ by a 1,3-dipolar cycloaddition reaction of porphyrin $\mathbf{1}$ with azomethine ylide. 


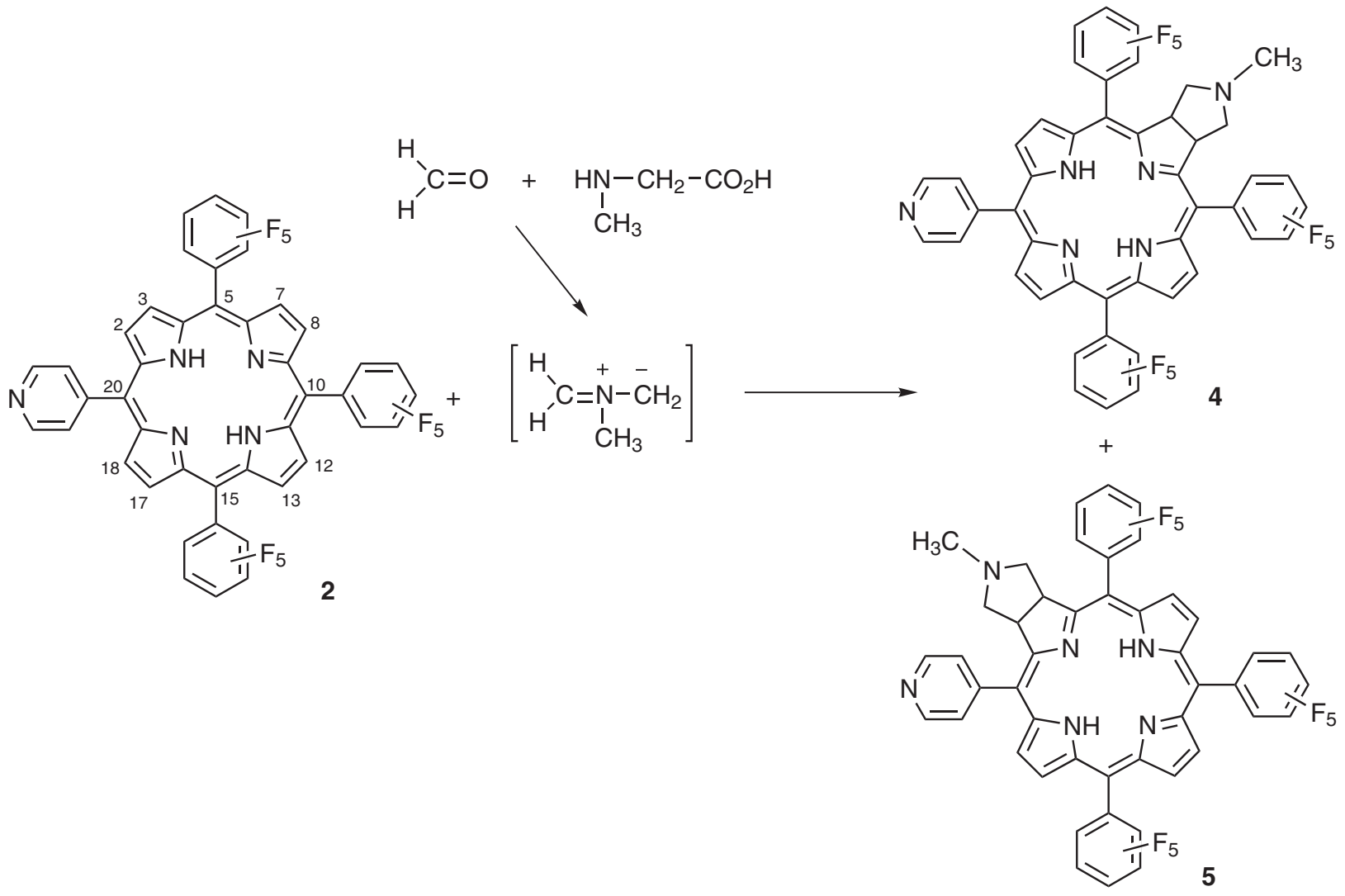

Scheme 2. Synthesis of chlorins $\mathbf{4}$ and $\mathbf{5}$ by a 1,3-dipolar cycloaddition reaction of porphyrin $\mathbf{2}$ with azomethine ylide.

NMR spectra were recorded on a Bruker Avance DRX300 instrument with tetramethylsilane as internal standard. The chemical shifts are expressed in $\delta(\mathrm{ppm})$ and the coupling constants $(J)$ in hertz $(\mathrm{Hz})$.

FAB-MS spectra were performed on a VG Analytical Autospec instrument using $\mathrm{CHCl}_{3}$ as solvent and metanitrobenzyl alcohol as matrix.

Elemental analyses were performed on a Leco 999 CHN analyzer.

Emission spectra were recorded on a Spex Triax Fluorolog 3, using spectroscopic grade methanol as solvent.

Photobleaching data were determined using a laser flash-photolysis apparatus containing a Continuum Q-switched Nd-YAG laser (Continuum, Santa Clara, CA) with excitation provided by the third harmonic at $\lambda=355 \mathrm{~nm}$. Pulse length was $8 \mathrm{~ns}$, beam diameter incident on sample was $6 \mathrm{~mm}$, and the repetition rate was $10 \mathrm{~Hz}$. Laser pulse was set up from 5 to $10 \mathrm{~mJ}$ per pulse in the photobleaching studies. The total amount of energy used was controlled by the bleaching no higher than $10 \%$ the sample initial absorbance.

The uric acid test was recorded on a MMD-Optics Laser (power of $40 \mathrm{~mW}$ ), coupled to a Hewlett Packard 8543 spectrophotometer.
Analytical thin-layer chromatography (TLC) was carried out on sheets pre-coated with silica gel (Merck 60, $0.2 \mathrm{~mm}$ thick). Column chromatography was carried out with silica gel (Merck 37-63 mm and Fluka 0.04-0.063 $\mu \mathrm{m}$ for flash chromatography) and Florisil (Merck).

Synthesis of 5,10,15-tris(pentafluorophenyl)-20-(4pyridyl)porphyrin, (2)

A mixture of 4-pyridinecarbaldehyde $(0.69 \mathrm{~mL}, 6.9$ $\mathrm{mmol})$ and pentafluorobenzaldehyde $(3.50 \mathrm{~mL}, 21 \mathrm{mmol})$ in glacial acetic acid $(115 \mathrm{~mL})$ was heated under reflux and magnetic stirring. Distilled pyrrole $(1.9 \mathrm{~mL}, 28 \mathrm{mmol})$ was then added to this solution. After $30 \mathrm{~min}$, the crude product was pre-purified by chromatography on Florisil using dichloromethane/ petroleum ether (3:1) as eluent. Further purification was performed using a mixture of dichloromethane/ cyclohexane (4:1) as eluent.

Two porphyrins were obtained: 5,10,15,20tetrakis(pentafluorophenyl)porphyrin, (1), and the new 5,10,15-tris(pentafluorophenyl)-20-(4-pyridyl)porphyrin, (2). The desired porphyrin 2 was further purified by chromatography on a silica gel column (Merck 37-63 mm) using $8 \%$ acetone in dichloromethane as eluent. Since the porphyrin obtained was still impure, another column 
chromatography on silica was carried out using dichloromethane as eluent; this allowed the isolation of $80 \mathrm{mg}$ of pure porphyrin 2.

Data for porphyrin $2 .{ }^{1} \mathrm{H}$ NMR $\delta-2.58(\mathrm{~s}, 2 \mathrm{H}, \mathrm{NH})$, 8.17 (dd, 2 H, $J 4.4$ and $J 1.2$, H-2, 6-Py), 8.88 (d, 2 H, J 3.6, H-2, 18), 8.92 (d, 2 H, J 3.6, H-3, 17), 8.93 (s, 4 H, H-7, 8, $12,13), 9.07$ (dd, $2 \mathrm{H}, J 4.4$ and $J 1.2, \mathrm{H}-3,5-\mathrm{Py})$. MS FAB ${ }^{+}$ $\mathrm{m} / \mathrm{z} 886[\mathrm{M}+\mathrm{H}]^{+} .{ }^{15,16}$

Synthesis of chlorins 4, (5,10,20-tris(pentafluorophenyl)15-(4-pyridyl)-tetrahydro-1H-N-methyl-pyrrolo [3,4b]porphyrin and 5, (5,10,15-tris(pentafluorophenyl)-20-(4pyridyl)-tetrahydro-1H-N-methyl-pyrrolo [3,4-b]porphyrin)

Chlorins $\mathbf{4}$ and $\mathbf{5}$ were obtained by the same synthetic methodology described for the synthesis of chlorin $3 .{ }^{13} \mathrm{~A}$ toluene solution $(3 \mathrm{~mL})$ of porphyrin $2(25 \mathrm{mg}, 0.028 \mathrm{mmol})$, $\mathrm{N}$-methylglycine (20 mg, $0.22 \mathrm{mmol}$ ) and paraformaldehyde $(17 \mathrm{mg}, 0.56 \mathrm{mmol})$ was heated, at reflux, for $10 \mathrm{~h}$ under nitrogen atmosphere. TLC of the reaction mixture revealed the formation of two new products. After solvent evaporation, the obtained residue was purified by flash chromatography using a dichloromethane/acetone $(9: 1)$ mixture. The unchanged starting porphyrin 2 ( $7.6 \mathrm{mg}, 31 \%)$ was eluted first and was followed by the new chlorin 4 (7.3 $\mathrm{mg}, 28 \%)$. The other chlorin 5 (5.5 $\mathrm{mg}, 21 \%)$ was then eluted with a dichloromethane/acetone (2:1) mixture.

Data for chlorin 4. ${ }^{1} \mathrm{H}$ NMR $\delta-1.67$ and $-1.65(2 \mathrm{~s}, 2 \mathrm{H}$, $\mathrm{NH}), 2.21\left(\mathrm{~s}, 3 \mathrm{H}, \mathrm{CH}_{3}\right), 2.53-2.60$ and 3.09-3.14 $(2 \mathrm{~m}, 4 \mathrm{H}$, H-methylene), 5.24-5.25 (m, $2 \mathrm{H}, \mathrm{H}-7,8), 8.02$ and 8.10 (2d, $2 \mathrm{H}, J$ 4.7, H-2, 6-Py), 8.31 and 8.37 (2d broad, $2 \mathrm{H}, J$ $4.7, \mathrm{H}-\beta), 8.42$ and 8.46 (2d, $2 \mathrm{H}, J$ 4.7, H-17, 18), 8.68 (d broad, $2 \mathrm{H}, J 4.7, \mathrm{H}-\beta), 9.01$ and $9.02(2 \mathrm{~d}, 2 \mathrm{H}, J 4.7, \mathrm{H}-3,5-$ Py). MS FAB ${ }^{+} \mathrm{m} / \mathrm{z} 943(\mathrm{M}+\mathrm{H})^{+}, 886\left[\left(\mathrm{M}-\mathrm{C}_{3} \mathrm{H}_{7} \mathrm{~N}\right)+\mathrm{H}\right]^{+}$. Anal. Calc for $\mathrm{C}_{46} \mathrm{H}_{21} \mathrm{~F}_{15} \mathrm{~N}_{6}{ }^{1 / 2} \mathrm{H}_{2} \mathrm{O}: \mathrm{C}, 58.05 ; \mathrm{H}, 2.33 ; \mathrm{N}$, 8.83. Found: C, $58.02 ; \mathrm{H}, 2.68 ; \mathrm{N}, 8.61 \%$.

Data for chlorin 5. ${ }^{1} \mathrm{H}$ NMR $\delta-2.00$ and $-1.94(2 \mathrm{~s}, 2 \mathrm{H}$, $\mathrm{NH}), 2.14$ (s, $\left.3 \mathrm{H}, \mathrm{CH}_{3}\right), 2.44-2.54$ (m, $2 \mathrm{H}, \mathrm{H}$-methylene), 2.99 and 3.11 (2t, $2 \mathrm{H}, J$ 8.3, H-methylene), 5.23 and 5.43 (2dd, $2 \mathrm{H}, J 16.4$ and $J 8.3, \mathrm{H}-2,3), 7.96$ and $7.99(2 \mathrm{~d}, 2 \mathrm{H}$, $J$ 4.9, H-2, 6-Py), 8.38 and 8.41 (2d, $2 \mathrm{H}, J$ 4.9, H- $\beta$ ), 8.49 and $8.51(2 \mathrm{~d}, 2 \mathrm{H}, J 4.8, \mathrm{H}-12,13), 8.66$ and $8.72(2 \mathrm{~d}, 2 \mathrm{H}$, $J$ 4.9, H- $\beta$ ), 9.01 and 9.07 (2d, 2 H, $J$ 4.9, H-3, 5-Py). MS $\mathrm{FAB}^{+} m / z 943(\mathrm{M}+\mathrm{H})^{+}, 886\left[\left(\mathrm{M}-\mathrm{C}_{3} \mathrm{H}_{7} \mathrm{~N}\right)+\mathrm{H}\right]^{+}$. MS-HRFAB exact mass $\mathrm{m} / \mathrm{z}$ for $\mathrm{C}_{46} \mathrm{H}_{22} \mathrm{~N}_{6} \mathrm{~F}_{15}(\mathrm{M}+\mathrm{H})^{+}$: calculated, 943.1666, found 943.1665 .

\section{Photobleaching measurements}

Light intensities were determined by ferrioxalate actinometry after each photolysis run. The $1 \mathrm{~cm}$ path length quartz sample solution cell was thermostated at $25^{\circ} \mathrm{C}$. The sample solution was continuously stirred throughout the flash-photolysis experiment. ${ }^{17}$

In a typical experiment, a $2 \mathrm{~mL}$ sample of $\sim 2 \mu \mathrm{mol} \mathrm{L} \mathrm{L}^{-1}$, photosensitizer in dimethylsulfoxide, of each chlorin ( 3 or 4) was placed in a $1 \mathrm{~cm}$ path length quartz cell with a microstirring magnet bar. Irradiations (under air-saturated conditions) and absorbance measurements were performed on each sample in the same cell. Measurements were made in triplicate for each condition. The absorption spectra (300-800 nm) were recorded using a U-3000 Hitachi spectrophotometer before the radiation $\left(\mathbf{A}_{0}\right)$ and after various irradiation times $\left(\mathbf{A}_{\mathbf{t}}\right)$.

Uric acid (UA) test

In order to verify the photodynamic activity of chlorins 3 and 4, the uric acid test was carried out. ${ }^{14,18} \mathrm{~A} 1 \mathrm{~cm}$-pathlength cell containing an ethanolic solution of each chlorin $\left(10^{-5} \mathrm{~mol} \mathrm{~L}^{-1}\right)$ and uric acid $\left(10^{-3} \mathrm{~mol} \mathrm{~L}^{-1}\right)$ was irradiated at $683 \mathrm{~nm}$ using a $40 \mathrm{~mW}$ solid-state laser and stirred under saturated air conditions. The absorbance measurements were performed directly on the cell at pre-determined time intervals.

The Photodynamic activity scale (PA) obtained for chlorins could be mathematically determined by the modified Fischer expression. ${ }^{19}$

$\mathrm{PA}=\Delta \mathrm{A}_{\mathrm{UA}} 10^{5} / \mathrm{Wt}_{\mathrm{PS} \lambda \text { iir }}$

$\mathbf{P A}=$ photodynamic activity; $\boldsymbol{\Delta} \mathbf{A}_{\mathrm{UA}}=\mathrm{UA}$ absorbance decrease at $293 \mathrm{~nm}$ in UA and PS solution after irradiation; $\mathbf{W}=$ laser power $(\mathrm{mW}) ; \mathbf{t}=$ irradiation time (second) and $\mathbf{A}_{\mathrm{PS} \text { irr }}=$ absorbance of photosensitizer (PS) in UA and PS solution after irradiation.

\section{Results and Discussion}

Synthesis and characterization of porphyrin 2

Porphyrin 2 was synthesized by a crossed Rothemund reaction according to previosly reported conditions. ${ }^{20-22}$ This synthesis involves the condensation of pyrrole with 4-pyridinecarbaldehyde and pentafluorobenzaldehyde, under reflux for $30 \mathrm{~min}$ in acetic acid at $118{ }^{\circ} \mathrm{C}$. Under such conditions, a mixture of porphyrin 1 and the desired porphyrin $\mathbf{2}$ were directly obtained. In this synthesis, pyrrole, 4-pyridinecarbaldehyde and pentafluorobenzaldehyde were used in a 4:1:3 molar ratio. The synthesis was monitored through UV-Vis spectra. The synthesized porphyrin 2 shows typical optical spectrum 
consisting of a dominant Soret band $\left(\lambda_{\max }=414 \mathrm{~nm}\right)$ and two less intense bands in the visible region $\left(\lambda_{\max }=500\right.$ to $650 \mathrm{~nm}$ ), labelled as Q bands (Table 1). This spectrum is similar to the one due to $5,10,15,20$-tetrakis(pentafluorophenyl)porphyrin, (1), indicating that the substitution of a pentafluorophenyl group by a 4-pyridyl group in one of the meso positions does not significantly affect the spectrum pattern.

Table 1. UV-Vis. data for porphyrins $\mathbf{1}$ and $\mathbf{2}$, in dichloromethane, and for chlorins $\mathbf{3 ,} \mathbf{4}$ and $\mathbf{5}$ in DMSO

\begin{tabular}{lcccc}
\hline $\begin{array}{l}\text { Compound } \\
\text { (solvent) }\end{array}$ & Soret $^{\mathrm{a}}$ & Q IV & Q II & Q I $^{\mathrm{a}}$ \\
\hline $\mathbf{1}(\mathrm{DCM})$ & $412(5.57)$ & 506 & 582 & $636(\mathrm{w})$ \\
$\mathbf{2}$ (DCM) & $414(5.49)$ & 508 & 584 & $638(\mathrm{w})$ \\
$\mathbf{3}$ (DMSO) & $406(5.28)$ & 504 & 598 & $651(4.72)$ \\
$\mathbf{4}(\mathrm{DMSO})$ & $406(4.75)$ & 504 & - & $648(4.18)$ \\
$\mathbf{5}$ (DMSO) & $406(4.75)$ & 504 & - & $648(4.18)$ \\
\hline
\end{tabular}

${ }^{a} \lambda, \mathrm{nm}(\log \varepsilon) ; \mathrm{w}=$ weak

However, porphyrin $2{ }^{1} \mathrm{H}$ NMR spectrum is quite different from that of porphyrin $\mathbf{1}$, as shown in Table 2. While in porphyrin $\mathbf{1}$ all $\beta$-pyrrolic protons are equivalent (they appear as a singlet), in porphyrin $\mathbf{2}$ they appear as three different groups of signals (two doublets corresponding to four protons $\mathrm{H}-2, \mathrm{H}-3, \mathrm{H}-17$ and $\mathrm{H}-18$ and one singlet due to other four protons $\mathrm{H}-7, \mathrm{H}-8, \mathrm{H}-12$ and $\mathrm{H}-13$ ).

The assignment of the proton resonances of porphyrin 2 was carried out based on its ${ }^{1} \mathrm{H}$ NMR features and by taking into account the literature data available for other similar compounds. According to data reported by James et al. ${ }^{22}$ and Lindsay et al. ${ }^{23}$ for 4-pyridyl protons the double doublet at $\delta 8.17(\mathrm{~J} 4.1$ and $1.5 \mathrm{~Hz})$ was attributed to the 4-Py protons $\mathrm{H}-2$ and $\mathrm{H}-6$, while the double doublet at $\delta 9.07(J 4.1$ and $1.5 \mathrm{~Hz}$ ) was assigned to the 4-Py protons $\mathrm{H}-3$ and $\mathrm{H}-5$. As for the $\beta$-pyrrolic protons of porphyrin 2, the singlet at $\delta 8.93$ was attributed to the $\beta$-pyrrolic protons H-7, H-8, H-12 and H-13, which are situated between two pentafluorophenyl substituents and are thus equivalent. The doublet at $\delta 8.88(\mathrm{~J} 3.6 \mathrm{~Hz})$ was assigned to the $\beta$ pyrrolic protons $\mathrm{H}-2$ and $\mathrm{H}-18$, while the doublet at $\delta 8.92$ $(J 3.6 \mathrm{~Hz}$ ) was assigned to the $\beta$-pyrrolic protons $\mathrm{H}-3$ and $\mathrm{H}-17$. The latter protons, being closer to the pentafluorophenyl group should present a chemical shift value identical to that found for H-7, H-8, H-12 and H-13.

On the other hand, $\mathrm{H}-2$ and $\mathrm{H}-18$, are closer to the 4-Py group, and thus appear in a more shielded region of the spectrum since the pyridine group is less electronegative than the pentafluorophenyl one.

\section{Synthesis and characterization of chlorins $\mathbf{4}$ and $\mathbf{5}$}

The new chlorins $\mathbf{4}$ and $\mathbf{5}$ were synthesized as described in the experimental part. This synthesis considers a 1,3-dipolar cycloaddition between porphyrin 2 and the azomethine ylide generated in situ from $N$-methylglycine and paraformaldehyde, ${ }^{13}$ (Scheme 2).

Both chlorins show photophysical properties similar to those of the porphyrin systems, but have enhanced and red-shifted $Q$ bands. Such chlorins show $\lambda_{\max }=648 \mathrm{~nm}$ in DMSO (Table 1).

The structures of chlorins $\mathbf{4}$ and $\mathbf{5}$ were assigned on the basis of their ${ }^{1} \mathrm{H}$ NMR spectra (Table 2). The minor chlorin 5 showed two double doublets at $\delta 5.23$ and $5.43(\mathrm{H}-2$ and $\mathrm{H}-3)$ and one $\mathrm{AB}$ spin system at $\delta 8.49$ and $8.51 \mathrm{ppm}$,

Table 2. ${ }^{1} \mathrm{H}$ NMR spectral data for compounds 1, 2, 4 and 5

\begin{tabular}{|c|c|c|c|c|c|c|c|}
\hline Compound & Pyrrolic $\beta$ - $\mathrm{H}^{\mathrm{a}}$ & 3,5-Py & 2,6-Py & H-methylene & $\begin{array}{c}\text { Pyrrolic } \\
\beta-\mathrm{C}\left(\mathrm{sp}^{3}\right)-\mathrm{H}\end{array}$ & $\mathrm{CH}_{3}$ & $\mathrm{NH}$ \\
\hline 1 & $8.93 \mathrm{~s}(8)$ & - & - & - & - & - & $-2.92 \mathrm{~s}(2)$ \\
\hline 2 & $\begin{array}{l}8.88 \mathrm{~d}(2) \\
8.92 \mathrm{~d}(2) \\
8.93 \mathrm{~s}(4)\end{array}$ & $9.07 \mathrm{dd}(2)$ & $8.17 \mathrm{dd}(2)$ & - & - & - & $-2.58 \mathrm{~s}(2)$ \\
\hline 4 & $\begin{array}{l}8.31 \mathrm{~d}(1), \\
8.37 \mathrm{~d}(1), \\
8.42 \mathrm{~d}(1), \\
8.46 \mathrm{~d}(1), \\
8.68 \mathrm{~d}(2)\end{array}$ & $\begin{array}{l}9.01 \mathrm{~d}(1) \\
9.02 \mathrm{~d}(1)\end{array}$ & $\begin{array}{l}8.02 \mathrm{~d}(1) \\
8.10 \mathrm{~d}(1)\end{array}$ & $\begin{array}{l}2.53-2.60 \mathrm{~m} \mathrm{(2)} \\
3.09-3.14 \mathrm{~m} \mathrm{(2)}\end{array}$ & $5.24-5.25 \mathrm{~m} \mathrm{(2)}$ & $2.21 \mathrm{~s}(3)$ & $\begin{array}{l}-1.67 \mathrm{~s}(1), \\
-1.65 \mathrm{~s}(1)\end{array}$ \\
\hline 5 & $\begin{array}{l}8.38 \text { d (1), } \\
8.41 \text { d (1), } \\
8.49 \text { d (1), } \\
8.51 \text { d (1), } \\
8.66 \text { d (1), } \\
8.72 \text { d (1) }\end{array}$ & $\begin{array}{l}9.01 \mathrm{~d}(1) \\
9.07 \mathrm{~d}(1)\end{array}$ & $\begin{array}{l}7.96 \mathrm{~d}(1) \\
7.99 \mathrm{~d}(1)\end{array}$ & $\begin{array}{c}2.44-2.54 \mathrm{~m}(2) \\
2.99 \mathrm{t}(1) \\
3.11 \mathrm{t}(1)\end{array}$ & $\begin{array}{l}5.23 \text { dd (1), } \\
5.43 \text { dd (1) }\end{array}$ & $2.14 \mathrm{~s}(3)$ & $\begin{array}{l}-2.00 \mathrm{~s}(1) \\
-1.94 \mathrm{~s}(1)\end{array}$ \\
\hline
\end{tabular}

${ }^{a}$ chemical shifts (ppm) in $\mathrm{CDCl}_{3}$, multiplicity (number of protons). 
corresponding to the resonance of the two $\beta$-pyrrolic protons $\mathrm{H}-12$ and H-13. These data are only compatible with the structure of $\mathbf{5}$. In contrast, the major chlorin $\mathbf{4}$ displayed one multiplet at $\delta$ 5.24-5.25 for the two $\beta$-pyrrolic protons $\mathrm{H}-7$ and $\mathrm{H}-8$, and two doublets at $\delta 8.42$ and 8.46 for $\mathrm{H}-17$ and $\mathrm{H}-18$. The difference observed in the resonance of the signals of H-17 and H-18 indicates that the chemical environment of these protons is quite different. This ${ }^{1} \mathrm{HNMR}$ spectrum is compatible with structure 4 .

\section{Photobleaching experiments}

Upon irradiation, most of the photosensitizers used in biomedical studies are degraded. The resistance of dyes to degradation by light has been investigated, however, the mechanism of photodegradation and the nature of photoproducts has not often been determined..$^{8-11}$ It is believed that the photobleaching of a sensitizer is caused by singlet oxygen (Type II process) attack, although free radicals (Type I process) may be involved. ${ }^{24}$ The factor that determines whether a Type I or Type II reaction occurs is the competition between substrate and molecular oxygen for the triplet sensitizer. Thus, the process is oxygen-concentration dependent. The chemical nature of the sensitizer and substrate also influences the extent of their reactions. ${ }^{25}$

In this paper, the absorbance (Table 1) at a specific wavelength for each dye $\left(\mathbf{A}_{t}\right)$ was used to estimate the photobleaching quantum yield $\left(\boldsymbol{\phi}_{\mathbf{P h}}\right)$. $\boldsymbol{\phi}_{\mathbf{P h}}$ at various times, $\mathbf{t}$, was determined as the ratio between the number of mols of photobleached dye ( $\left.\mathbf{n}_{\text {Dye }}^{\mathbf{t}}\right)$ and the number of mols of photons absorbed by the solution during the same time $\left(\mathbf{n}_{\mathbf{P h}}^{\mathbf{t}}\right)$. The following relationship allows the calculation of $\mathbf{n}_{\text {Dye }}^{\mathbf{t}}$ :

$\mathrm{n}_{\text {Dye }}^{\mathrm{t}}=\left[\left(\mathrm{A}_{0}-\mathrm{A}_{\mathrm{t}}\right) / \varepsilon \mathrm{L}\right] \mathrm{V}_{\mathrm{s}}$

where $\mathbf{L}$ is the optical path length (in $\mathrm{cm}$ ), $\varepsilon$ is the dye molar absorption coefficient at a specific wavelength (in $\mathrm{mol}^{-1} \mathrm{~L} \mathrm{~cm}^{-1}$ ) and $\mathbf{V}_{\mathrm{s}}$ is the volume of the sample (in litres). The number of photons absorbed by the sample $\mathbf{n}_{\mathbf{P h}}^{\mathbf{t}}$ can be obtained by dividing the total light energy absorbed by the solution during the irradiation time $\mathrm{t}\left(\mathbf{I}_{\mathbf{a b s}}^{\mathrm{t}}\right)$, by the energy of 1 Einstein of photons at the used excitation wavelength. That is the reason why Abs at the irradiation wavelength decreased exponentially with time. $\mathbf{I}_{\text {abs }}^{\mathbf{t}}$ can be expressed by:

$\mathrm{I}_{\mathrm{abs}}^{\mathrm{t}}=\mathrm{I}_{\mathrm{o}} \int_{0}^{\mathrm{t}}\left[1-10^{-\mathrm{Ao}} \exp (-\mathrm{kt})\right] \mathrm{dt}$

where $\mathbf{I}_{\mathbf{0}}$ is the incident energy (in $\mathrm{J} \mathrm{s}^{-1}$ ) and $\mathbf{k}$ is the photodegradation rate constant (in $\mathrm{s}^{-1}$ ) obtained from the slope of a plot of $\operatorname{In}\left(\mathbf{A}_{0} / \mathbf{A}_{t}\right)$ versus the elapsed time in seconds.
The photodegradation quantum yield $\phi_{\mathrm{Ph}}^{\mathrm{t}}$ can thus be determined using the following relation. ${ }^{18}$

$\phi_{\mathrm{Ph}}^{\mathrm{t}}=\frac{\left(\mathrm{A}_{0}-\mathrm{A}_{\mathrm{t}}\right) \mathrm{V}_{\mathrm{s}}}{\varepsilon \mathrm{L} \mathrm{N}_{\mathrm{Ph}} \int_{0}^{\mathrm{t}}\left[1-10^{-\mathrm{Ao}} \exp (-\mathrm{kt})\right] \mathrm{dt}}$

with $\mathbf{N}_{\mathbf{P h}}$, being the photon flux at the excitation wavelength $\lambda$, being equal to $\mathbf{I}_{0} \lambda / \mathbf{N}_{\mathrm{A}}$.hc (in mol photons $\mathrm{s}^{-1}$ ) and $\mathbf{N}_{\mathrm{A}}$ being Avogadro's number, $\mathrm{h}$ is Planck's number and $\mathrm{c}$ is the velocity of light in vacuum. ${ }^{18}$

The photobleaching of chlorins $\mathbf{3}$ and $\mathbf{4}$ in DMSO was studied. In both cases, no new distinctive absorption peaks appeared in the spectral region between 300 and $800 \mathrm{~nm}$ after irradiation. This behaviour led us to conclude that during the irradiation time, the only absorbing species present in the system are the only absorbing species present in the system are the clorin molecules and no significant photobleaching effect will be critical in the photodynamic activity of the dye. The photobleaching of the new chlorin 4 is shown in Figure 1. Chlorin 3 presented a similar behaviour.
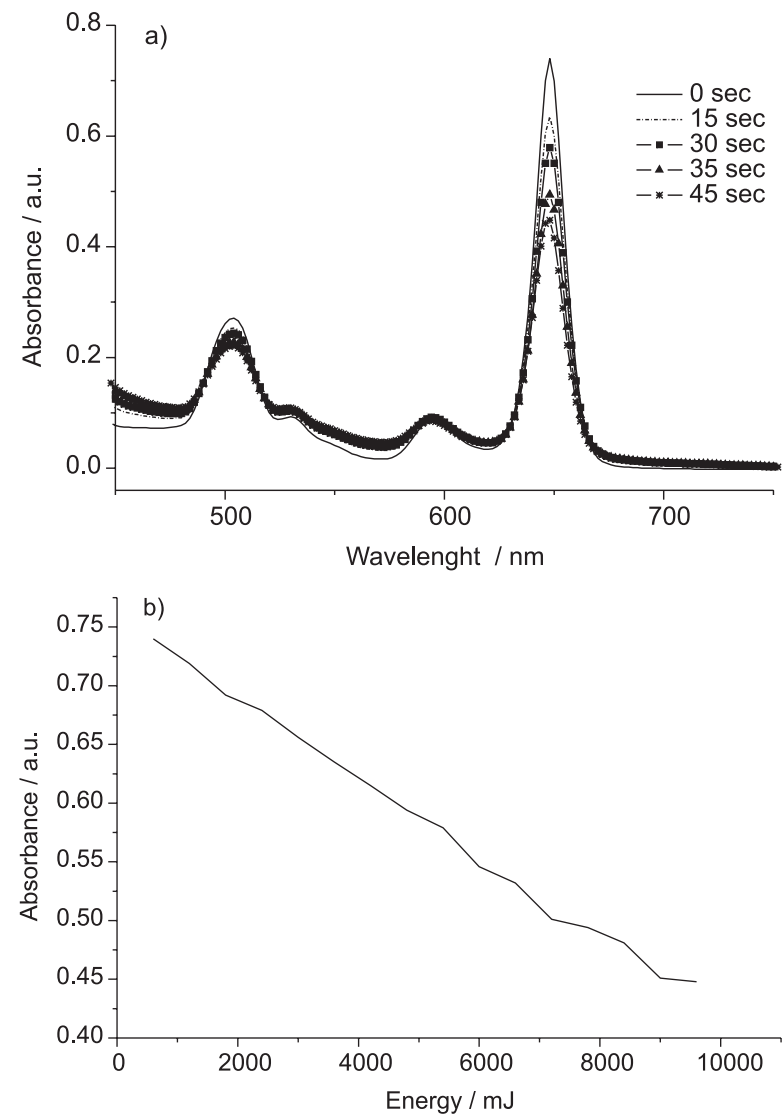

Figure 1. a) Changes in the visible spectrum of chlorin 4, at an initial concentration of $2 \mu \mathrm{mol} \mathrm{L}^{-1}$ in DMSO, in equilibrium with air, upon irradiation at the third harmonic at $355 \mathrm{~nm}$, using a laser flash-photolysis apparatus consisting of Continuum Q-switched NdYAG laser (Continuum, Santa Clara, CA); b) Degradation of chlorin 4, $200 \mathrm{mJs}^{-1}$. 
Figure 1a shows the absorption spectra of chlorin 4, in the range $450-750 \mathrm{~nm}$, before and after irradiation with an increasing dose until the maximum of $9.8 \mathrm{~J} \mathrm{~cm}^{-2}$ at $355 \mathrm{~nm}$. After irradiation the chlorin absorption bands at 418 and $648 \mathrm{~nm}$ decreased and this is indicative of the photobleaching process. Figure $1 \mathrm{~b}$ shows absorption decrease for chlorin 4.

The photobleaching quantum yields $\left(\phi_{\mathrm{Ph}}^{\mathrm{t}}\right)$ were determined using the above mentioned equations. The photobleaching quantum yields $\left(\phi_{\mathrm{Ph}}\right)$ obviously depend on the dye used, and the values found were $0.12 \mathrm{~mol}$ Einstein ${ }^{-1}$ for chlorin 3 and 0.047 mol Einstein $^{-1}$ for chlorin 4. These results seem to demonstrate that the substitution of a fluorophenyl group for a pyridyl one increases the molecules aggregation process and leads to a reduction in the photobleaching quantum yield. This effect has been observed for other photosensitizers where aggregation processes are directly related to the photobleaching ones. ${ }^{8-11}$ Aggregated species are more resistant to photobleaching than the monomeric ones.

\section{Uric acid test with chlorins $\mathbf{3}$ and $\mathbf{4}$}

Hadjur et al. ${ }^{18}$ reported that some porphyrins in solution appear to produce singlet oxygen $\left({ }^{1} \mathrm{O}_{2}\right)$ associated with photodynamic activity or secondary photodegradation process mediated by self-generated ${ }^{1} \mathrm{O}_{2}$. In order to test photodynamic activity modulated by ${ }^{1} \mathrm{O}_{2}$, chlorins $\mathbf{3}$ and 4 were irradiated in the presence of uric acid, a classical acceptor of ${ }^{1} \mathrm{O}_{2}$ molecules.

The spectra of the chlorins did not show any decrease in the dye Soret or Q band (Figure 2). The parameters (irradiation wavelength, fluency rate, irradiation time, photosensitizer concentration) remained constant. After laser irradiation at $683 \mathrm{~nm}$, specific degradation of uric acid in the solution containing chlorin $\mathbf{4}$ was observed, which is characterized by the decrease in the $293 \mathrm{~nm}$ band as shown in Figure 2. A similar behaviour was observed for chlorin 3. Table 3 presents the results of the variation of uric acid 293 $\mathrm{nm}$ absorption band in solutions containing chlorins $\mathbf{3}$ and 4 after laser irradiation at $683 \mathrm{~nm}$. Photodynamic activity was determined by the modified Fischer's expression.

The slightly higher photodynamic activity $(\mathrm{PA}=83)$ observed for $\mathbf{3}$, if compared with that obtained for $\mathbf{4}$ $(\mathrm{PA}=57)$, can also be explained by considering some aggregation of $\mathbf{4}$ in solution. This behavior is in agreement with the lower photodegradation of $\mathbf{4}$, as already mentioned. Despite its slightly lower photodynamic efficiency in oxygen singlet production, the chlorin 4 seems to be a promising photosensitizer for PDT if one considering its lower photodegradation.

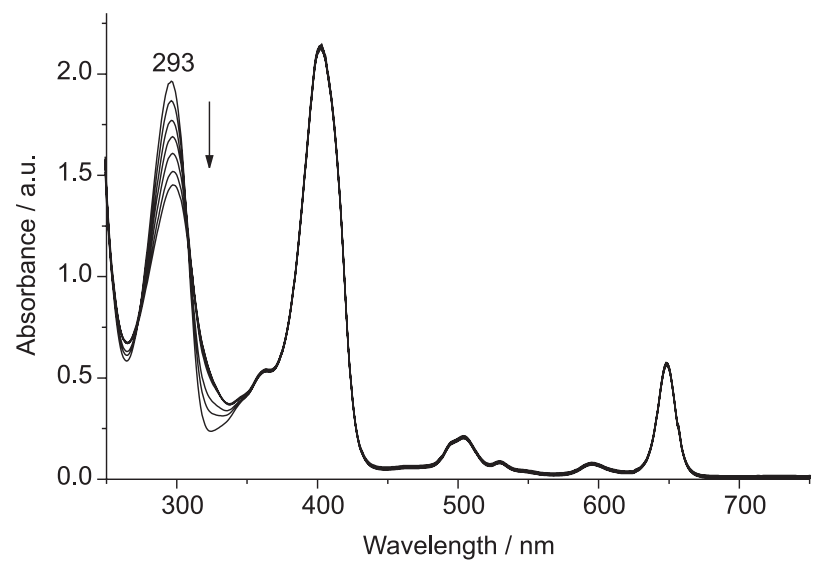

Figure 2: Degradation of uric acid $(293 \mathrm{~nm})$ in ethanol solution containing chlorin 4, after laser irradiation at $683 \mathrm{~nm}$ for $1 \mathrm{~s}, 4 \mathrm{~s}$, $240 \mathrm{~s}, 570 \mathrm{~s}, 840 \mathrm{~s}, 1320 \mathrm{~s}$ and $1740 \mathrm{~s}$.

Table 3. Photodynamic Activity of chlorins $\mathbf{3}$ or $\mathbf{4}$ in ethanol, after laser irradiation at $683 \mathrm{~nm}$

\begin{tabular}{cccc}
\hline Chlorin & $\Delta \mathrm{A}_{\mathrm{UA}}$ & $\mathrm{A}_{\mathrm{PS} \text { hirr }}$ & $\mathrm{PA}$ \\
\hline $\mathbf{3}$ & 0.600 & 0.0201 & 83 \\
$\mathbf{4}$ & 0.135 & 0.0065 & 57 \\
\hline
\end{tabular}

$\overline{\Delta \mathrm{A}_{\mathrm{UA}}=\text { UA absorbance decrease at } 293 \mathrm{~nm} \text { in UA and PS solution }}$ after irradiation, $\mathrm{A}_{\mathrm{PS} \lambda \mathrm{irr}}=$ absorbance of PS in UA and PS solution at $683 \mathrm{~nm}$ (laser irradiation wavelength), PA = photodynamic activity.

\section{Conclusions}

The results presented here establish a new group of porphyrin derivatives (chlorins) potentially useful for PDT. The synthesis and chemical characterization have been described and some of their photophysical properties have been considered. Further work on the evaluation of other photophysical features and also on these chlorins in vitro activities using neoplastic cell lines is being carried out with promising preliminary results.

\section{Acknowledgements}

We are grateful to CAPES, CNPq, FAPESP and GRICES, respectively the Brazilian and Portuguese funding agencies, for supporting this work.

\section{References}

1. McLain, J. L.; Lee, J.; Groves, J. T. In Biomimetic Oxidations Catalyzed by Transition Metal Complexes; Meunier, B. ed., Imperial College Press: London, 2000, p. 91; Weiss, R.; Gold, A.; Trautwein, A. X.; Terner, J. In The Porphyrin Handbook; Kadish, K. M.; Smith, K. M.; Guilard, R., eds., Academic Press: London, 2000, vol. 4, p. 65.; Dolphin, D.; Traylor, T. G.; Xie, L.Y.; Acc. Chem. Res. 1997, 30, 251. 
2. Ostovic, D.; Bruice, T. C; Acc. Chem. Res. 1992, 25, 314; Bhyrappa, P.; Young, J. K.; Moore, J. S.; Suslick, K. S.; J. Mol. Catal. A: Chem. 1996, 113, 109; Gonsalves, A. M. d'A R; Serra, A. C.; J. Porphyr. Phthalocyanines 2000, 4, 598.

3. Vialas, C.; Pratviel, G.; Claparols, C.; Meunier, B.; J. Am. Chem. Soc. 1998, 120, 11548; McClure, J. E.; Baudouin, L.; Mansuy, D.; Marzilli, L. G.; Biopolymers 1997, 42, 203.

4. Bigey, P.; Frau, S.; Loup, C.; Claparols, C.; Bernadou, J.; Meunier, B.; Bull. Soc. Chim. Fr. 1996, 133, 679.

5. Ma, L. F.; Dolphin, D.; Can. J. Chem. 1997, 75, 262.

6. Driaf , K.; Granet, R.; Krausz, P.; Kaouadji, M.; Thomasson, F.; Chulia, A. J.; Verneuil, B.; Spiro, M.; Blais, J. C.; Bolbach G.; Can. J. Chem. 1996, 74, 1550.

7. Adam, K. R.; Berenbaum, M. C.; Bonnett, R.; A, Nizhnik; N.; Salgado, A.; Valles, M. A.; J. Chem. Soc., Perkin Trans. I 1992 1465.

8. Bonnett, R.; Martinez, G.; Tetrahedron 2001, 57, 9513.

9. Machado, A.E.H.; Quim. Nova 2000, 2, 237.

10. Pandey, R. K.; Zheng, G. In The Porphyrin Handbook; Kadish, K. M.; Smith, K. M.; Guilard, R., eds., Academic Press: London, 2000, vol. 6, p. 157.

11. Cubeddn, R.; Keir, W. F.; Rampson, R.; Truscott, T. G.; Photochem. Photobiol. 1987, 46, 633.

12. Tomé, A. C.; Lacerda, P. S. S.; Neves, M. P. G. S.; Cavaleiro, J. A. S.; Chem. Commun. 1997, 1199.

13. Silva, A. M. G.; Tomé, A. C.; Neves, M. P. G. S.; Silva, A. M. S.; Cavaleiro, J. A. S.; Chem. Commun. 1999, 1767.

14. Fischer, F.; Granchew, G.; Sinn, H-J.; Maier-Borst, W.; Lorenz, W. J.; Schlag, P. M.; Clin. Chim. Acta 1998, 274, 89.
15. Azevedo, D. A.; Neto, F. R. A.; Quim. Nova 1991, 14, 262.

16. Lavorenti, A.; Hudson, H. R.; Pianka, M.; Quim. Nova 1990, 13,24

17. Bunce, N. J. In Handbook of Organic Photochemistry; Scaiano, J. C., ed., CRC Press: Boca Raton, 1990, ch. 9, p. 241.

18. Hadjur, C.; Lange, N.; Rebstein, J.; Monnier, P.; van den Berg, H.; Wagnières, G.; J. Photochem. Photobiol. B:Biol. 1998, 45, 170.

19. Neri, C.R.; Maestrin-Prado, A. P. J.; Ribeiro, A. O.; Serra, O. A.; Iamamoto Y.; Materials Science 2002, 20, 69.

20. Adler, A. D.; Longo, F. R.; Finarelli, J. D.; Goldmacher, J.; Assour, J.; Korsakoff, L.; J. Org. Chem. 1967, 32, 467.

21. Little, R. G.; Anton, J. A.; Loach, P. A.; Ibers, J. A.; J. Heterocycl. Chem. 1975, 12, 343.

22. Meng, G. G.; James, B. R.; Skov, K. A; Can. J. Chem. 1994, $72,1894$.

23. Leonard, D. R.; Lindsay-Smith, J. R.; J. Chem. Soc., Perkin Trans. II 1990, 2, 1917.

24. Hongying, Y.; Fuyuan W.; Zhiyi, Z.; Dyes Pigm. 1999, 43, 109.

25. Di Mascio, P.; Medeiros, M. H. G.; Bechara, E. J. H.; Catalani, L. H.; Ciencia e Cultura, 1995, 47, 297.

Received: November 24, 2003

Published on the web: November 12, 2004

FAPESP helped in meeting the publication costs of this article. 